\title{
Food Habits and Diet Relationship in the Redbelly Tilapia (Tilapia zillii) and Guenther's Mouthbrooder (Chromidotilapia guntberi) from an Abandoned Gold Mine Reservoir, Southwestern Nigeria
}

\author{
Olusola O. KOMOLAFE, Timothy O. AMOO*, \\ Michael O. AWODIRAN \\ Obafemi Awolowo University, Faculty of Science, Department of Zoology, Ile-Ife, \\ Nigeria; niyikomolafe2002@yahoo.co.uk; amootimothy@gmail.com (*corresponding author);michfemi@yahoo.com
}

\begin{abstract}
The food and feeding habits of the redbelly Tilapia (Tilapia zillii) and Guenther's mouthbrooder (Chromidotilapia guntheri) was investigated in an abandoned gold mine reservoir at Igun from June 2013 to May 2014. Using a cast net and gillnet fishing gears, 370 fish individuals were caught and their stomach contents were analysed by using the frequency of occurrence and numerical methods. Tilapia zillii comprised 53.78\% (199 individuals) while Chromidotilapia guntheri covered up the remaining percentage $(46.22 \%)$ which is made up of 171 individuals. Food items in the stomachs of $T$. zillii individuals predominantly consisted of detritus, mud, and algae (77.97\%) while those in C. guntheri individuals mostly consisted fish remains, detritus and algae (81.67\%). T. zillii exploited more food items (23 of 27) as compared to C. guntheri (17 of 27). The Schoener's index value for the species was 0.65 . This study showed that $T$. zillii and C. guntheri exhibited benthopelagic exploitation and are mainly herbivorous and omnivorous respectively based on the food items observed in the stomach contents of these species. The fish species fed on related food items as confirmed by Schoener's overlap index (0.65), suggesting that there was overlap in the dietary requirements of the two species. This index value, however, was probably not an indication of competition for food between these two species because they exploited abundant food sources.
\end{abstract}

Keywords: competition; diet overlap; fishes; freshwater; food items; food preference

\section{Introduction}

Interactions and inter-relationships are evident among fishes of a community during their search for food. Some species prey on other organisms or are being preyed upon, thereby forming a food chain or web (Valeila, 1991). This signifies the transfer of energy from one trophic level to another. It is also observed that fish species sometimes compete for food. Diet overlap among fish species or among size classes of a single species has been calculated in several studies to help explain community structure or to clarify competitive relationships (Zaret and Rand, 1971; Keast, 1978; Wallace Jr, 1981). Among the several measures of diet used in overlap indexes, the Horn (1966) and Schoener (1970) indexes give values from 0 (no overlap) to 1 (complete overlap) and measure the overlap between two species. Overlap in the other indexes is generally considered to be biologically significant when the value exceeds 0.60
(Zaret and Rand, 1971; Mathur, 1977). (Hurlbert, 1978) rejected certain overlap indexes as not appropriate because the overlap index values are dependent on the proportion of food in a category for one species when that category is not utilized by the other species. In addition, all measures of overlap that do not consider resource availability are poor measures, although the (Schoener, 1970) index is considered to be adequate in the absence of resource availability data (Hurlbert, 1978).

Many biologists invoke competitive exclusion to explain the niche separation of sympatric species. The "competitive exclusion principle" states that if two non-interbreeding populations occupying the same ecological niche are sympatric, one will ultimately exclude the other (Hutchinson, 1965). Therefore, sympatric species that differ in any aspect of their niche are said to owe their "character divergence" to competition in the past. Lindström and Nilsson (1962) reported that competition as the interaction between fish species or individuals adversely 
affects survival or individual growth within populations.

Fishes have responded to various biotic and abiotic factors that control their feeding habits or patterns, through a number of characters and strategies. Therefore, fishes feed on different kinds of food ranging from plants, decayed plants and animals, detritus, insects, eggs of other fishes, mud deposits, mollusc, worms, crabs, algae, plankton and other small fishes (Adesulu and Sydenham, 2007). Habitat plays a large part in the feeding behaviour of fishes. Within the habitat exists, spectrums of good to poor feeding sites, which will be reflected by the spatial distribution of animals seeking to maximize food intake (Wańkowski and Thorpe, 1979). The most important factor that affects the feeding habit of fishes is the availability of food (Sirois and Boisclair, 1995). This is why fishes are highly selective in their feeding system despite the abundance of food (Komolafe, 1984).

The feeding of freshwater fish has been extensively investigated in West Africa particularly in Ghana (Blay, 1985) and Nigeria. In Nigeria, studies have been performed in Lake Kainji (Imevbore and Bakare, 1970; Arawomo, 1976; Olatunde, 1979); in upper Ogun River (Adebisi, 1981); in Lagos and Lekki Lagoons (Fagade, 1971; Fagade and Olaniyan, 1973) and in a number of rivers in the Niger Delta area (Brown, 1985; Tetsola, 1988; Odum, 1992). Recent works on food and feeding of fish include the work of Oboh et al. (2003) on twenty-three fish species from River Jamieson, a tributary of Benin River. Oribhabor and Ogbeibu (2012) on twenty-five species of fish in Buguma Creek, Niger Delta, Nigeria; Ekpo et al. (2014) seventeen fish species from Qua Iboe River estuary, Akwa Ibom State; and Abdul et al. (2016) on 8 species of fish including Tilapia zillii from Ogun estuary, Ogun State (all in Nigeria). Information on the feeding habits of fish species will aid the study of trophic relationships (Baijot and Moreau, 1997). Stomach content analyses have long been used to assess diet composition and assign trophic level in marine organisms (Hyslop 1980; Cortés 1999). Quantitative analyses of stomach contents provide an important tool to understand and elucidate predator-prey interactions (Cortés, 1997; Dávalos and Gónzalez, 2003), feeding behaviour patterns (Preciado et al., 2006), and ontogenetic shifts (Armstrong et al., 1996). In addition, estimation of prey abundance, the frequency of occurrence, weight and relative importance of food items can provide critical ecological information (Joyce et al., 2002; Ibáñez et al., 2004).

Tilapias are mainly herbivorous, with flexible and opportunistic feeding habits (Trewavas, 1982). The success of Tilapia in Nigeria freshwaters probably depended on a wide diverse feeding regime (Fagade, 1971; Abayomi et al., 2005). Every organic organism, plants, and mineral matters small enough to pass through the oesophagus are found in the gut of Tilapia fishes (Bowen, 1982). The dominant plant composition of Tilapia food is made up of phytoplankton, filamentous algae, and fine sediment rich in both diatoms and bacteria while the animal part is more of zooplankton (Olaleye, 1980; Adesulu, 1981).

There is no adequate work on the food and feeding behaviour, including diet composition of T. zillii and $C$. guntheri in habitats that are highly polluted e.g., abandoned gold mine reservoir of Igun, South-Western Nigeria (Lawal and Komolafe 2012). In this study, we examined the feeding and diet habits of the redbelly tilapia (Tilapia zillii) and Guenther's mouthbrooder (Chromidotilapia guntheri) from the gold mine reservoir. These two species were studied because of their ecological role and abundance in the reservoir.

\section{Materials and Methods}

\section{Study area}

This study was carried out in an abandoned gold mining reservoir at Igun, Southwestern Nigeria. Igun is a small village where the inhabitants are predominantly farmers. The study area lies within the equatorial rainforest vegetation belt where the climate is hot and humid in most months of the year. The catchment area of Igun gold mine reservoirs extends from Longitude $004^{\circ} 40^{\prime} 9.5^{\prime \prime}$ -

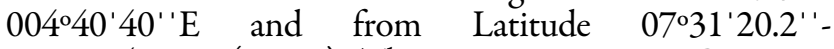
$07^{\circ} 31^{\prime} 54.9^{\prime} \mathrm{N}$ (Fig. 1). The Nigerian Mining Company impounded three streams (Oika, Eleripon, and Osun) to make the reservoirs in 1941. Reservoirs 1, 2, and 3 were covered with rooted aquatic macrophytes, which disallowed the use of gill net. Reservoir 4 was being used by the community for core services and was partly covered by aquatic macrophytes while reservoir 6 had been overgrown with higher plants. All the above reasons made reservoirs 1 , $2,3,4$, and 6 not inappropriate for fish sampling in the course of this research. Hence, fish were sampled only in reservoir 5.

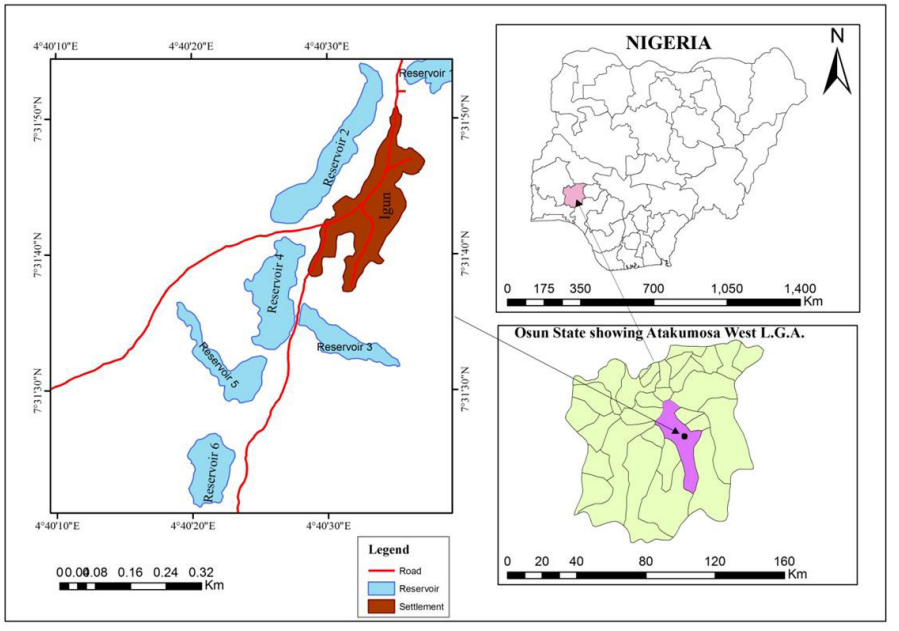

Fig. 1. Map of Nigeria showing abandoned gold mine reservoirs at Igun village 
150

\section{Fish sampling}

Samples of fish were collected from reservoir 5 (Fig. 2) from 9 AM-12 PM on every sampling day, each month from June 2013 to May 2014. Cast net (with a mesh size of $2.5 \mathrm{~cm}$ ) and traps, made from Eremospatha sp. with entrances in the form of a funnel and with non-return valves, were used to collect fish samples under contract with the local artisanal fishermen. The traps were baited with ripe palm fruits and set under sedges. This ensured that actively feeding fish were caught. All the fish samples were brought into the laboratory in an ice chest covered with ice for preservation. Standard identification keys (Paugy et al., 2003; Adesulu, 2007) were used to identify fish species. Fish biometric data such as the total length $(\mathrm{cm})$, standard length, and body mass $(\mathrm{g})$ of individual fish from the samples were measured and recorded. Fish lengths were measured to the nearest $0.1 \mathrm{~cm}$ while and weight measured to the nearest $0.1 \mathrm{~g}$ using Denward balance Scale, Serial No. 9512. Each fish specimen was smitten open from the anus to the pectoral fin and the stomach carefully removed. Each stomach was then preserved in $4 \%$ formalin solution in a well-labelled sample bottle for identification. The contents of each stomach were carefully removed into a petri-dish for observation using a compound microscope.

The analysis of the stomach contents was carried using frequency of occurrence and numerical methods (Hyslop, 1980; Costa et al., 1992). The frequency of occurrence is the number of stomachs of a species in which each type of food item occurred and expressed as a percentage of the total number of stomachs of that species examined, in order to determine the proportion of the fish population that fed on a particular food item (Hynes, 1950). In the numerical method, the number of each food item was expressed as the percentage of the total number of food items found the stomach.

\section{Schoener's overlap index $(C)$}

The Schoener (1970) overlap index was used to establish dietary affinity between the 2 species. Based on a review of dietary overlap measures (Cailliet and Barry, 1979; Linton et al., 1981), the index was chosen because it was found to measure overlap accurately over most of the range of potential overlap. The incorporation of resource availability into an overlap index would enhance measurement of overlap if technical and theoretical problems were overcome. When resource availability data are absent, the Schoener index is one of the least objectionable indexes available (Wallace Jr, 1981). Schoener's index, Cxy, between species $\mathrm{x}$ and $\mathrm{y}$ was calculated as:

$$
C x y=1-1 / 2\left(\sum_{i=1}^{n}|P x, i-P y, i|\right)
$$

where $P_{x, \mathrm{i}}$ and $P_{y, i}$ are the frequencies (or proportions) of species $x$ and $y$ respectively in category $i$. The index ranges from 0 which indicates no dietary overlap to a maximum overlap of 1 when all prey items are found in equal proportions. Diets of different species can normally be regarded as significantly different when the overlap index value is below 0.6 (Zaret and Rand, 1971; Wallace Jr, 1981). Cartes and Sardà (1989) took index values $\leq 0.8$ to be indicative of significant differences because the dietary overlap considered in their work was between different size classes of the same species in the same habitat.

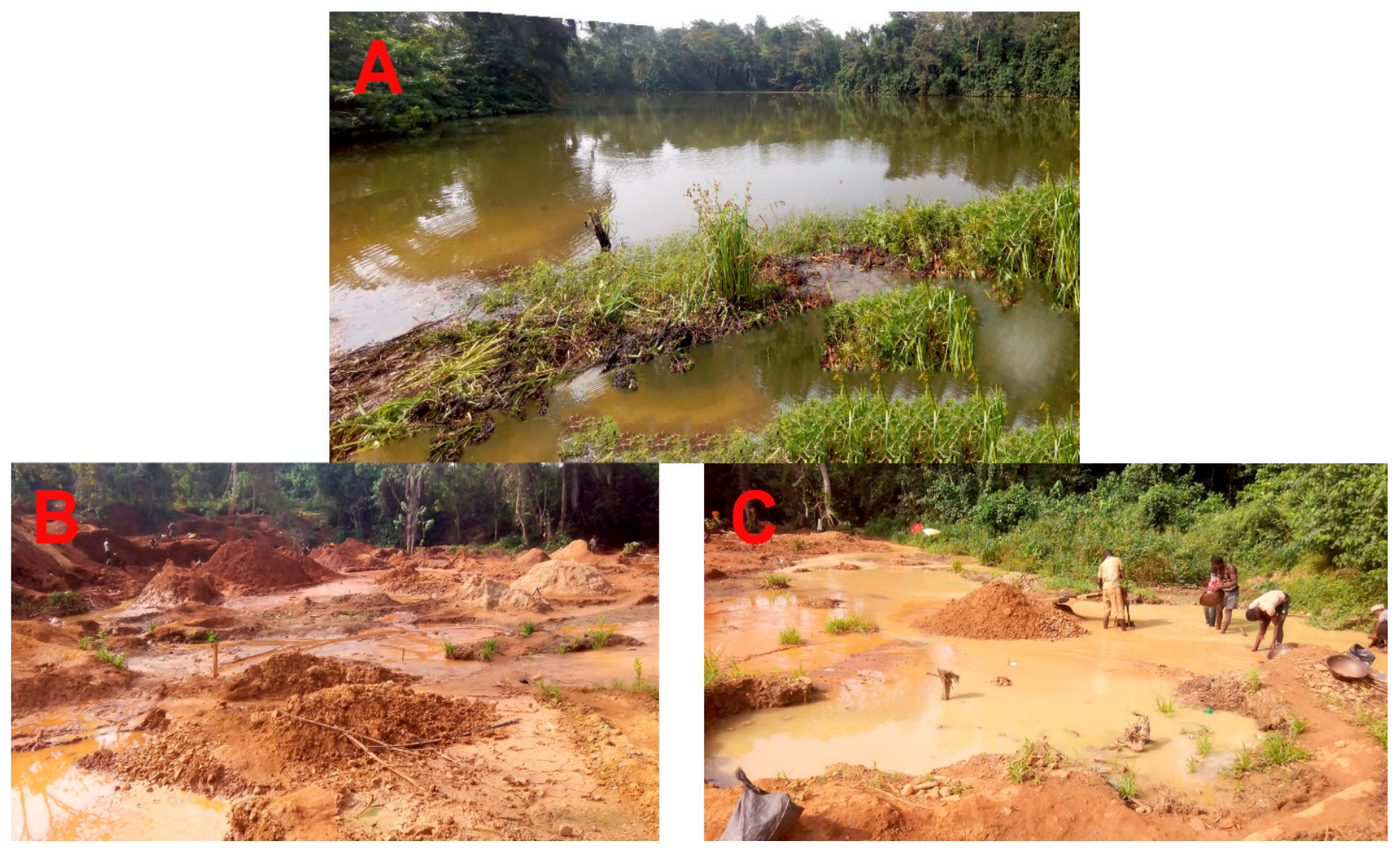

Fig. 2. Reservoir 5 at Igun showing (A) its view and the surrounding vegetation, (B) heaps of earth at the nearby mining site and,

(C) miners at work processing gold with their locally made equipment 


\section{Statistical analysis}

Data were analysed by the use of IBM SPSS Statistics for Windows, (Version 21.0). Descriptive statistics of fish biometric data were presented as means \pm standard errors of the mean. Statistical difference between a total number of fish individuals caught during the rainy and dry seasons for the species from Igun reservoir was analysed using unpaired t-test.

\section{Results}

A total of 370 fish individuals, made up of a family (Cichlidae) and two species were recorded in Igun reservoir during the study (Table 1). T. zillii was higher in number (53.78\%) than C. guntheri (46.22\%). There was no significant difference $(\mathrm{P}<0.05)$ in the mean number of individuals caught during the rainy season $(3.90 \pm 1.46$ and $12.29 \pm 1.13$ for $T$. zillii and C. guntheri respectively) to those caught in the dry season $(17.00 \pm 2.24$ each for $T$. zillii and C. guntheri). The mean total- and standard lengths and weight were $16.00 \pm 6.06 \mathrm{~cm}, 12.95 \pm 4.83 \mathrm{~cm}$ and $123.7 \pm 118.06 \mathrm{~g}$ for $T$. zillii; $13.04 \pm 1.75 \mathrm{~cm}, 10.04 \pm 1.42$ $\mathrm{cm}$, and $38.00 \pm 16.45 \mathrm{~g}$ for C. guntheri. T. zillii fed on more food items (23 of 27) than C. guntheri (17 of 27) (Table 2). Table 3 reveals that the food of T. zillii showed variation in the dry and rainy seasons. A high proportion of algae, diatoms, insects, crustaceans and fish parts were fed upon during the rainy season (April to September) while mud, detritus and higher plants fragments complemented the diet during this period. In the dry season (OctoberMarch), T. zillii fed on algae, insects, detritus, higher plant fragments, and mud. C. guntheri had a slight variation in its food items in relation to the two seasons.

During the dry and rainy seasons, the species fed predominantly on higher plants fragments, fish remains, algae, detritus, and diatoms. The inclusion of insect remains in the dry season was the slight variation in the seasons.

Table 4 shows that both fed predominantly on algae $(85.47 \%$ and $55.98 \%$ for $T$. zillii and C. guntheri respectively) by the percentage of the number of prey items observed. In addition, the second largest food items consumed by $C$. guntheri were diatom (32.40\%). Other food items of importance found in the stomach of T. zillii included fish parts (eggs and scales, 5.40\%) and plants fragment $(4.65 \%)$ while those in the stomach of C. guntheri included diatom (32.40\%) and fish remains $(6.72 \%)$. The diet of the fishes included both the blue-green and green algae, which were filamentous or unicellular. In T. zillii, Closterium sp. and Oscillatoria sp. were very prominent in its diet while Microcystis sp. and Closterium sp. were the major algae in the diet of $C$. guntheri. The three main diets of $T$. zillii were detritus, mud, and algae and constituted $77.97 \%$ of its total prey items (Fig. 3). In C. guntheri, fish remains, detritus, and algae were the main three contents of its stomach food item composition and these constituted $81.67 \%$ of the total food items (Fig. 4). The Schoener's overlap index value of 0.65 was obtained for the species in the reservoir, suggesting a dietary overlap between the species (Table 4).

\section{Discussion}

In the present study, T. zillii and C. guntheri fed on similar food items such as algae, insects, higher plant fragments, detritus, and diatoms. However, algae, higher plant fragments, and detritus were the only common food items fed upon by the species.

Other food items were fed upon at variance. A number of factors are attributable to changes in the feeding habits of fish species. Fryer and Iles (1972) and Jobling (1995) listed these factors as the size of the fish, sex, season, water temperature, habitat, and competition. Because of the feeding rhythm of T. zillii, the species have been variously classified as plankton feeders, higher plant and algae feeders or macrophagous as well as mudsuckers (Fagade, 1971; Brown and Colgan, 1984). According to (Spataru, 1978), adult Tilapia zillii are considered to be voracious herbivores, often decreasing plant density and changing the composition of native plants which can threaten many native aquatic organisms that depend on such plants for forage, protection, or spawning. In this study, T. zillii was largely herbivorous with its food similar to that in the report of Akintunde (1976) in Lake Kainji, Komolafe (1984) in Opa reservoir and Abdul et al. (2016) in Ogun estuary.

Table 1. Relative abundance and seasonal distributions of Tilapia zillii and Chromidotilapia guntheri from the Igun gold mine reservoir

\begin{tabular}{|c|c|c|c|c|c|c|c|}
\hline \multirow{3}{*}{ Fish species } & \multicolumn{4}{|c|}{ Fish catch } & \multirow{3}{*}{$\begin{array}{c}\% \text { total catch by } \\
\text { species }\end{array}$} & \multirow{3}{*}{$\mathrm{t}$} & \multirow{3}{*}{ Sig. (2-tailed) } \\
\hline & \multicolumn{2}{|c|}{ Rainy season } & \multicolumn{2}{|c|}{ Dry season } & & & \\
\hline & $\mathrm{N}$ & $\mathrm{X} \pm \mathrm{SE}$ & $\mathrm{N}$ & $\mathrm{X} \pm \mathrm{SE}$ & & & \\
\hline Tilapia zillii & 114 & $3.90 \pm 1.46$ & 85 & $17.00 \pm 2.24$ & 53.78 & -0.28 & 0.79 \\
\hline $\begin{array}{c}\text { Chromidotilapia } \\
\text { guntheri }\end{array}$ & 86 & $12.29 \pm 1.13$ & 85 & $17.00 \pm 2.47$ & 46.22 & -1.92 & 0.08 \\
\hline Total & 200 & & 170 & & 100 & & \\
\hline
\end{tabular}

Table 2. Biometric parameters of Tilapia zillii and Chromidotilapia guntheri sampled from Igun gold mine reservoir

\begin{tabular}{ccccc}
\hline \multirow{2}{*}{ parameter } & \multicolumn{2}{c}{ Tilapia zillii } & \multicolumn{2}{c}{ Chromidotilapia guntheri } \\
\cline { 2 - 5 } & Range & $\mathrm{X} \pm \mathrm{SD}$ & Range & $\mathrm{X} \pm$ SD \\
\hline Total length $(\mathrm{cm})$ & $9.1-27.7$ & $16.00 \pm 6.06$ & $9.7-16.8$ & $13.04 \pm 1.75$ \\
Standard length $(\mathrm{cm})$ & $7.4-22.0$ & $12.95 \pm 4.83$ & $7.5-12.8$ & $10.04 \pm 1.42$ \\
Weight $(\mathrm{g})$ & $13.0-375.0$ & $123.7 \pm 118.06$ & $13.0-84.0$ & $38.00 \pm 16.45$ \\
\hline
\end{tabular}


Table 3. Seasonal variations in the diets of Tilapia zillii and Chromidotilapia guntheri from Igun gold mine reservoir

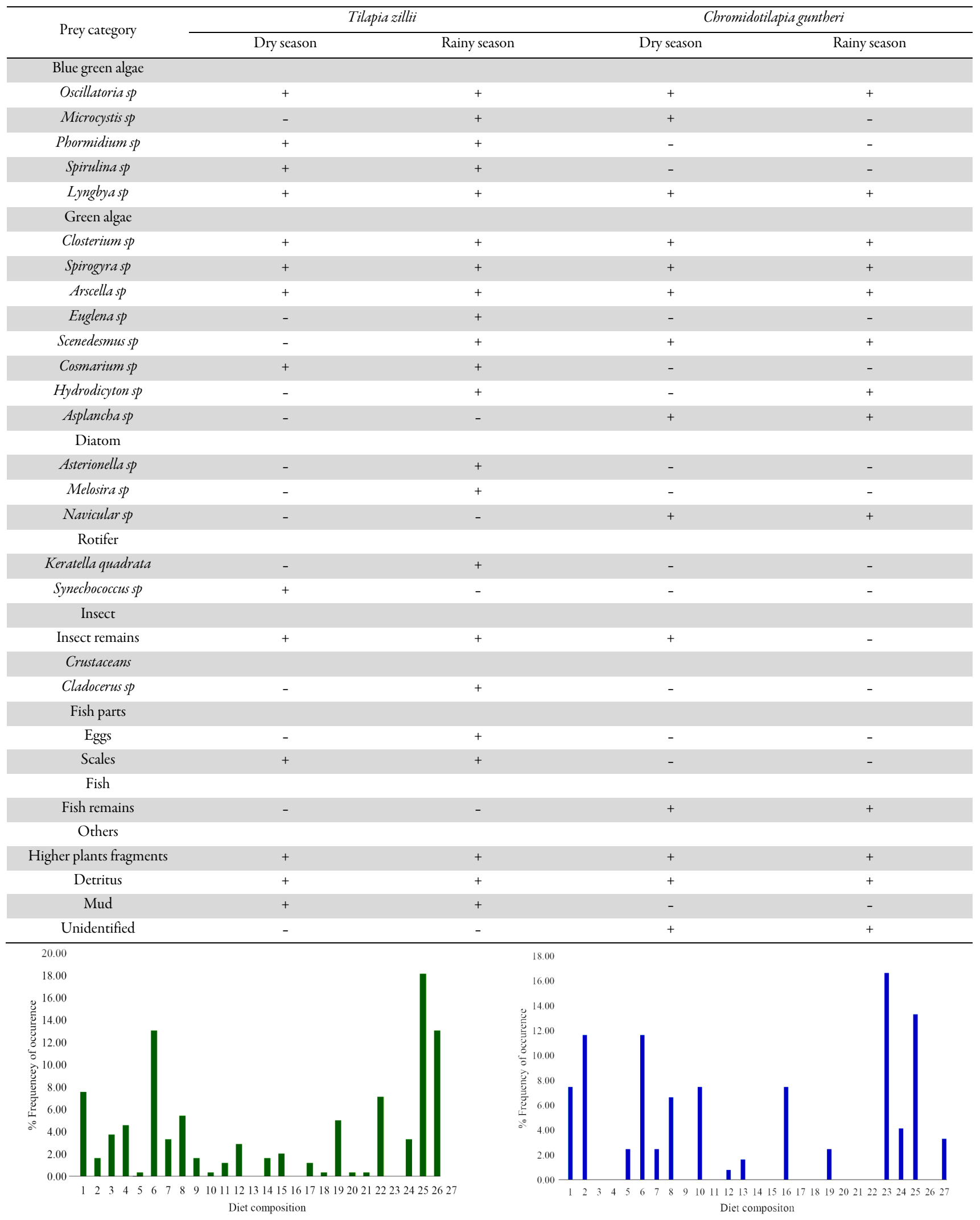

Fig. 3. Relative frequency of dietary composition of Tilapia zillii in Igun gold mine reservoir, Nigeria. Note: $1-13$ = algae; $14-16=$ diatom; $17-18$ = rotifer; $19=$ insect remains; $20=$ crustaceans; $21-22=$ fish parts; $23=$ fish remains; $24=$ plants fragment; $25=$ detritus; $26=$ mud; $27=$ unspecified
Fig. 4. Relative frequency of dietary composition of Chromidotilapia guntheri in Igun gold mine reservoir, Nigeria. Note: $1-13=$ algae; $14-16=$ diatom; $17-18=$ rotifer; 19 = insect remains; $20=$ crustaceans; $21-22=$ fish parts; $23=$ fish remains; $24=$ plants fragment; $25=$ detritus; $26=$ mud; $27=$ unspecified 
Table 4. Prey items observed $(\mathrm{N})$, percentage of prey items observed, $(\% \mathrm{~N})$, frequency of occurrence (Fo), percentage occurrence $(\% \mathrm{O})$, and diet overlap indexes of Tilapia zillii and Chromidotilapia guntheri from Igun reservoir

\begin{tabular}{|c|c|c|c|c|c|c|c|c|c|}
\hline \multirow{2}{*}{ Prey category } & \multicolumn{4}{|c|}{ Tilapia zillii } & \multicolumn{4}{|c|}{ Chromidotilapia guntheri } & \multirow{2}{*}{$C_{x}, y$} \\
\hline & $\mathrm{N}$ & $\% \mathrm{~N}$ & Fo & $\% \mathrm{O}$ & $\mathrm{N}$ & $\% \mathrm{~N}$ & Fo & $\% \mathrm{O}$ & \\
\hline Blue green algae & 4,283 & 46.22 & 43 & 18.22 & 377 & 37.81 & 26 & 21.67 & 0.65 \\
\hline Oscillatoriasp & 2.884 & 31.12 & 18 & 7.63 & 281 & 28.18 & 9 & 5.7 & \\
\hline Microcystis sp & 301 & 3.25 & 4 & 1.69 & 72 & 7.22 & 14 & 11.67 & \\
\hline Phormidium sp & 902 & 9.73 & 9 & 3.81 & - & 0 & - & 0 & \\
\hline Spirulina sp & 195 & 2.1 & 11 & 4.66 & - & 0 & - & 0 & \\
\hline Lyngbyasp & 1 & 0.01 & 1 & 0.42 & 24 & 2.41 & 3 & 2.5 & \\
\hline Green algae & 3,637 & 39.25 & 67 & 28.39 & 182 & 18.17 & 36 & 30 & \\
\hline Closterium $s p$ & 3,221 & 34.76 & 31 & 13.14 & 108 & 10.83 & 14 & 11.67 & \\
\hline Spirogyra sp & 52 & 0.56 & 8 & 3.39 & 21 & 2.11 & 3 & 2.5 & \\
\hline Arscellasp & 96 & 1.04 & 13 & 5.51 & 17 & 1.71 & 8 & 6.67 & \\
\hline Euglenasp & 25 & 0.27 & 4 & 1.69 & - & 0 & - & 0 & \\
\hline Scenedesmus sp & 1 & 1.01 & 1 & 0.42 & 24 & 2.41 & 9 & 7.5 & \\
\hline Cosmarium sp & 90 & 0.97 & 3 & 1.27 & - & 0 & - & 0 & \\
\hline Hydrodicyton sp & 152 & 1.64 & 7 & 2.97 & 1 & 0.1 & 1 & 0.83 & \\
\hline Asplancha sp & - & 0 & - & 0 & 11 & 1.01 & 2 & 1.67 & \\
\hline Diatom & 333 & 3.59 & 9 & 3.81 & 323 & 32.4 & 9 & 7.5 & \\
\hline Asterionella sp & 82 & 0.88 & 4 & 1.69 & - & 0 & - & 0 & \\
\hline Melosirasp & 251 & 2.71 & 5 & 2.12 & - & 0 & - & 0 & \\
\hline Navicular sp & - & 0 & - & 0 & 323 & 32.4 & 9 & 7.5 & \\
\hline Rotifer & 8 & 0.008 & 4 & 1.7 & 0 & 0 & 0 & 0 & \\
\hline $\begin{array}{l}\text { Keratella } \\
\text { quadrata }\end{array}$ & 5 & 0.05 & 3 & 1.27 & - & 0 & - & 0 & \\
\hline Synechococcussp & 3 & 0.03 & 1 & 0.42 & - & 0 & - & 0 & \\
\hline Insect & 24 & 0.26 & 12 & 5.09 & 12 & 1.2 & 3 & 2.5 & \\
\hline Insect remains & 24 & 0.26 & 12 & 5.08 & 12 & 1.2 & 3 & 2.5 & \\
\hline Crustacean & 1 & 0.01 & 1 & 0.42 & 0 & 0 & 0 & 0 & \\
\hline Cladocerussp & 1 & 0.01 & 1 & 0.42 & - & 0 & - & 0 & \\
\hline Fish part & 550 & 5.94 & 18 & 7.63 & 0 & 0 & 0 & 0 & \\
\hline Eggs & 500 & 5.4 & 1 & 0.42 & - & 0 & - & 0 & \\
\hline Scales & 50 & 0.54 & 17 & 7.2 & - & 0 & - & 0 & \\
\hline Fish & 0 & 0 & 0 & 0 & 67 & 6.72 & 20 & 16.67 & \\
\hline Fish remains & - & 0 & - & 0 & 67 & 6.72 & 20 & 16.67 & \\
\hline Others & 431 & 4.65 & 82 & 34.75 & 36 & 3.61 & 22 & 18.33 & \\
\hline $\begin{array}{l}\text { Higher plant } \\
\text { fragments }\end{array}$ & 431 & 4.65 & 8 & 3.39 & 26 & 2.61 & 5 & 4.17 & \\
\hline Detritus & - & 0 & 43 & 18.22 & - & 0 & 16 & 13.33 & \\
\hline Mud & - & 0 & 31 & 13.14 & - & 0 & - & 0 & \\
\hline Unidentified & - & 0 & - & 0 & 10 & 1 & 4 & 3.33 & \\
\hline Total & 9,276 & 100 & 236 & 100 & 997 & 100 & 120 & 100 & \\
\hline
\end{tabular}

This study is also in agreement with the study of Spataru (1978) and Olayemi (2000) who observed that T. zillii fed on whatever comes its way while searching for preferred food. According to their studies, its food consisted of algae, nematodes, arthropods, zooplankton, ostracods as well as chironomid larvae. Ifedayo (2006) had also reported T. zillii to feed on algae, higher plants, fish eggs and insect larvae in Osinmo reservoir. The species can, therefore, be said to have selectively fed on food items in the reservoir. The stomach contents of $C$. guntheri in Igun reservoir was dominated by fish, algae, diatoms, and insect remains. The food items were similar to food items recorded by Olayemi (2000) for Hemichromis fasciatus in Owalla reservoir. C. guntheri is an omnivore, feeding on whatever comes its way as observed in Owalla and Eko-Ende reservoirs by Taiwo (2008). The diatoms (Asterionella $s p$ and Melosira $s p$ ) recorded for $T$. zillii in the rainy season was not found in the diet during the dry season while Navicula sp appeared both in the dry and rainy seasons in the diet of $C$. guntheri. The variety of food items of $T$. zillii in this study was higher in number compared to the observations of (Walter, 2004; Abayomi et al., 2005) who reported plant materials and detritus for the species.

Since index values $>0.60$ are indicators of dietary overlap (Zaret and Rand, 1971; Langton, 1982), this suggests that there is overlap in the diets of T. zillii and $C$. guntheri $(C x y=0.65)$ from the gold mine reservoir. The feeding habits of fish had been found to overlap in some cases (Crozier, 1985; Yang and Livingstone, 1986). However, (Komolafe and Arawomo, 2011) reported no overlap in the feeding habits of Clarias gariepinus and Parachanna obscura in Osinmo reservoir. Since dietary overlap is dependent upon available resources (Keast, 1978), this diet overlap value might not be an indication of competition for food between these two species because they exploited abundant food sources (Ekpo et al., 2014). In spite of the high diet overlap value recorded $(0.67-0.90)$ between Kamchatka flounder and arrowtooth flounder size 
154

classes, (Yang and Livingstone, 1986) argued that there was probably no competition for food between these two species because they were exploiting abundant food sources.

There is fairly general agreement that studies of niche overlap (or equivalently, resource partitioning) are of interest because of their relevance to competition. According to (Schoener, 1974), the major purpose of resource partitioning studies is to analyse the limits interspecific competition places on the number of species that can stably coexist. A study by (Cody, 1974) which make extensive use of niche overlap data is essentially concerned with competition. In the article referred to above, Hurlbert (1978) suggests that niche overlap measures should serve "as a foundation for discussion of resource utilization strategies, competition, and species packing, and so on". It could also be argued that niche overlap is of interest in its own right, independent of any relationship to competition. Evolutionary forces (such as character displacement) and ecological forces (such as competitive exclusion) that determine observed overlap are directly related to competition, not niche overlap. An understanding of the reason for different levels of niche overlap in different communities will, therefore, requires that one understands both the competitive relationships between the species and the relationship between overlap and competition.

\section{Conclusions}

Exploitation of food resources differs between T. zillii and $C$. guntheri, with the different species exploiting separate levels of the available resources in the water column. This is a function of the food preferences when foraging during normal feeding activity.

\section{Acknowledgements}

This research received no specific grant from any funding agency in the public, commercial or not-for-profit sectors.

\section{References}

Abayomi O, Arawomo G, Komolafe O (2005). Distribution, food and feeding habits of a catfish, C. gariepinus (Burchell 1822) in Opa Reservoir, Ile Ife, Nigeria. Science Focus 10(1):62-67.

Abdul W, Omoniyi I, Agbon A, Adeosun F, Olowe O, Adekoya E (2016). Food and feeding habits of some fish species in Ogun State coastal estuary, Ogun State, Nigeria. Journal of Agricultural Science and Environment 16(1):61-74.

Adebisi A (1981). Analyses of the stomach contents of the piscivorous fishes of the upper Ogun River in Nigeria. Hydrobiologia 79(2):167-177.

Adesulu E (2007). The freshwater fishes and fisheries of Nigeria. Macmillan Nigeria Publishers Limited.

Adesulu EA, Sydenham DHJ (2007). The freshwater fishes and fisheries of Nigeria, Macmillan Nigeria Publishers Limited, Ibadan, pp 397.

Akintunde E (1976). The biology of Tilapia and Sarotherodon spp. Lake Kainiji, Nigeria, with special reference to Sarotherodon galilaeus. M. Phil Thesis. University of Ife, Nigeria.
Arawomo G (1976). Food and feeding of three Citharinus species in Lake Kainji, Nigeria. Journal of Fish Biology 9(1):3-10.

Armstrong MP, Musick JA, Colvocoresses JA (1996). Food and ontogenetic shifts in feeding of the goosefish, Lophius americanus. Journal of Northwest Atlantic Fishery Science 18:99-103.

Baijot E, Moreau J (1997). Biology and demographic status of the main fish species in the reservoirs of Burkina Faso. Hydrobiological aspects of fisheries in small reservoirs in the Sahel region. Technical Center for Agricultural and Rural Cooperation ACP-EU, Wageningen, Netherlands, pp 79-110.

Blay J (1985). Observations on the balance in fish populations in a small reservoir in Ghana. Fisheries Research 3:1-11.

Bowen S (1982). Feeding, digestion and growth-qualitative considerations. In International Conference on the Biology and Culture of Tilapias, Bellagio(Italy) 7:141-156.

Brown C (1985). The food and feeding relationship of non cichlid fishes of Ikpoba River, downstream of the dam, MSc Thesis, University of Benin, Benin City, Nigeria.

Brown JA, Colgan PW (1984). The ontogeny of feeding behaviour in four species of centrarchid fish. Behavioural Processes 9(4):395-411.

Cailliet G, Barry J (1979). Comparison of food array overlap measures useful in fish feedinghabit analysis."Gutshop 78:67-79.

Cartes J, Sardà F (1989). Feeding ecology of the deep-water aristeid crustacean Aristeus antennatus. Marine Ecology Progress Series. Oldendorf54(3):229-238.

Cody ML (1974). Competition and the structure of bird communities, Princeton University Press.

Cortés E (1997). A critical review of methods of studying fish feeding based on analysis of stomach contents: application to elasmobranch fishes. Canadian Journal of Fisheries and Aquatic Sciences 54(3):726-738.

Costa J, Assis C, Almeida P, Moreira F, Costa M (1992). On the food of the European eel, Anguilla anguilla (L.), in the upper zone of the Tagus estuary, Portugal.Journal of Fish Biology 41(5):841-850.

Crozier W (1985). Observations on the food and feeding of the angler-fish, Lophim piscatorius L, in the northern Irish Sea. Journal of Fish Biology 27(5):655-665.

Dávalos E, Gónzalez E (2003). Stomach content of one pelagic ray Dasyatis violacea (Bonaparte, 1832)(Rajiformes: Dasyatidae) from the Gulf of California, México.

Ekpo IE, Ibok-Essien M, Nkwoji JN (2014). Food and feeding habits and condition factor of fish species in Qua Iboe River estuary, Akwa Ibom State, southeastern Nigeria. Int. Journal of Fisheries and Aquatic Studies 2(2):38-46.

Fagade S (1971). The food and feeding habits of Tilapia species in the Lagos lagoon.Journal of Fish Biology3(2):151-156.

Fagade SO, Olaniyan CIO (1973). The food and feeding interrelationship of the fishes in the Lagos lagoon. Journal of Fish Biology 5(2):205-225.

Fryer G, Iles TD (1972). Cichlid fishes of the great lakes of Africa, their biology and distribution. Oliver and Boyd, Edinburgh.

Horn HS (1966). Measurement of "overlap" in comparative ecological studies. The American Naturalist 100(914):419-424.

Hurlbert S (1978). Results of five flamingo censuses conducted between November 1975 and December 1977. Andean Lake and Flamingo 
Investigations, San Diego State Univ, California, Tech. Rept.

Hurlbert SH (1978). The measurement of niche overlap and some relatives. Ecology 59(1):67-77.

Hutchinson GE (1965). The ecological theatre and the evolutionary play, Yale University Press.

Hynes H(1950). The food of fresh-water sticklebacks (Gasterosteus aculeatus and Pygosteus pungitius), with a review of methods used in studies of the food offishes. The Journal of Animal Ecology 36-58.

Hyslop E (1980). Stomach contents analysis - a review of methods and their application. Journal of Fish Biology 17(4):411-429.

Ibáñez CM, González C, Cubillos L (2004). Dieta del pez espada Xiphias gladius Linnaeus, 1758, en aguas oceánicas de Chile central en invierno de2003. Investigaciones marinas 32(2):113-120.

Ifedayo A (2006). Food and feeding habits of fishes inhabiting Osinmo reservoir, Ejigbo Local Government Area. Osun State, Nigeria. B.Sc, B.Sc. diss., Obafemi Awolowo University, Ile-Ife.

Imevbore A, Bakare O (1970). The food and feeding habits of non-cichlid fishes of the River Niger in the Kainji Reservoir area. Kainji Lake Studies 1:49-64.

Jobling M (1995). Fish bioenergetics. Oceanographic Literature Review 9(42):785.

Joyce W, Campana S, Natanson L, Kohler N, Pratt H, Jensen C (2002). Analysis of stomach contents of the porbeagle shark (Lamna nasus Bonnaterre) in the northwest Atlantic. ICESJournal of Marine Science: Journal du Conseil 59(6):1263-1269.

Keast A (1978). Trophic and spatial interrelationships in the fish species of an Ontario temperatelake.Environmental Biology of Fishes 3(1):7-31.

Komolafe O (1984). The biology of the Cichlid Fish Tilapia zillii (Gervais) in Opa reservoir Obafemi Awolowo University, Nigeria. M.Sc., Obafemi Awolowo University, Ile-Ife.

Komolafe OO, Arawomo GO (2011). Food and diet relationships of Parachanna obscura (Gunther) and Clarias gariepinus (Burchell) in a newly impounded Osinmo reservoir, Ejigbo, Nigeria. Cameroon Journal of Experimental Biology 7(1):9-15.

Langton R (1982). Diet overlap between Atlantic cod, Gadus morbua, silver hake, Merluccius bilinearis, and fifteen other northwest Atlantic finfish [Fish predators]. Fishery Bulletin United States, National Marine Fisheries Service.

Lindström T, Nilsson N-A (1962). On the competition between whitefish species. \& Holdgate, MW (eds.), The exploitation of natural animal populations 326-340.

Linton L, Davies RW, Wrona F (1981). Resource utilization indices: an assessment. The Journal of Animal Ecology 1:283-292.

Mathur D (1977). Food habits and competitive relationships of the bandfin shiner in Halawakee Creek, Alabama. American Midland Naturalist 89-100.

Oboh IP, Edema CU, Tongo O-L (2003). The food and feeding habits of fishes of the Jamieson River, Nigeria. Pakistan Journal of Scientific and Industrial Research 46(4):255-260.
Odum O (1992). The ecology and biology of the fishes of Ethiope River, Nigeria. PhD Thesis, University of Benin, Benin City, Nigeria.

Olatunde AA (1979). The food and feeding habits of Physalia pellucida and Schilbe mystus with notes on the diets of S. uranoscopus and Siluranodon auritus, family Schilbeidae (Osteichthyes: Siluriformes) in Lake Kainji, Nigeria. Freshwater Biology 9(3):183-190.

Olayemi A (2000). Food and feeding habits of fishes in Owalla reservoir, Osun State, Nigeria. M.Sc. diss., Obafemi Awolowo University, Ile-Ife.

Oribhabor B, Ogbeibu A (2012). The food and feeding habits of fish species assemblage in a Niger Delta Mangrove Creek, Nigeria. Journal of Fisheries and Aquatic Science 7(2):134.

Paugy D, Lévêque C, Teugels GG (2003). The fresh and brackish water fishes of West Africa.

Preciado I, Velasco F, Olaso I, Landa J (2006). Feeding ecology of black anglerfish Lophius budegassa: seasonal, bathymetric and ontogenetic shifts. Journal of the Marine Biological Association of the United Kingdom 86(04):877-884.

Schoener TW (1970). Nonsynchronous spatial overlap of lizards in patchy habitats. Ecology 51(3):408-418.

Schoener TW (1974). Resource partitioning in ecological communities. Science 185(4145):27-39.

Sirois P, Boisclair D (1995). The influence of prey biomass on activity and consumption rates of brook trout. Journal of Fish Biology 46(5):787805.

Spataru P (1978). Food and feeding habits of Tilapia zilli (Gervais)(Cichlidae) in Lake Kinneret (Israel). Aquaculture 14(4):327338.

Taiwo YF (2008). The taxonomy and some ecological aspects of fishes in two reservoirs in Osun State, Nigeria, $\mathrm{PhD}$ diss., Obafemi Awolowo University, Ile-Ife.

Tetsola E (1988). Distribution and feeding relationship of the fishes in Warri Rivers, Nigeria, Ph. D. Thesis, University of Benin, Benin City, Nigeria.

Trewavas E (1982). Tilapia: taxonomy and speciation [in Africa]. International Conference on the Biology and Culture of Tilapias, Bellagio(Italy), 2-5Sep 1980.

Valeila I (1991). Fundamentals of aquatic ecology. London, Longman Group.

Wallace Jr RK (1981). An assessment of diet-overlap indexes. Transactions of the American Fisheries Society 110(1):72-76.

Walter RJ, WilliamsJD (2004). US Geological Survey Circular, 1251.

Wańkowski J, Thorpe J (1979). Spatial distribution and feeding in Atlantic salmon, Salmo salar L. juveniles. Journal of Fish Biology 14(3):239-247.

Yang M, Livingstone PA (1986). Food habits and diet overlap of two congeneric species, Atheresthes stomias and Atheresthes evermanni, in the eastern BeringSea. Fishery Bulletin 82(3):615-623.

Zaret TM, Rand AS (1971). Competition in tropical stream fishes: support for the competitive exclusion principle. Ecology 52(2):336-342. 